\title{
POŠTA
}

TELEKOMUNIKÁCIE A

ELEKTRONICKÝ OBCHOD

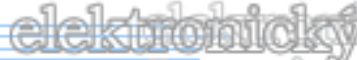

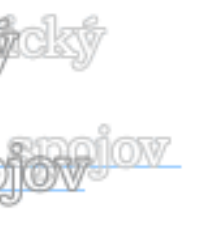

\section{VPLYV NÁSTROJOV VIRÁLNEHO MARKETINGU NA NÁVŠTEVNOSŤ WEBOVÝCH STRÁNOK V PODMIENKACH UNIVERZITY}

\author{
Radovan Madleňák ${ }^{1}$, Lucia Madleňáková ${ }^{2}$, Alena Pacherová ${ }^{3}$
}

\begin{abstract}
This article is focused in web traffic problem of the website of the Department of Communications, University of Žilina. At the beginning the viral tools that are used by universities as a form of raising awareness of their universities names are analyzed. The aim of the research was the monitoring of the impact of specific viral marketing tools for raising web traffic website of the Department of Communications. The visit rate of the website was measured by Google Analytics, YouTube Analytics and also through Facebook Insights. At the end of the article the correlation analysis was used for the evaluation of the efficiency of viral marketing tools.
\end{abstract}

Keywords: viral marketing, WWW pages, Youtube, Facebook, correlation

\section{1 Úvod}

Ak si uvedomíme, aké existujú v dnešnej dobe možnosti prezentácie a aká vysoká je ich efektívnost', je možné konštatovat', že vytvorenie prezentácia sa na internete je tá najlepšia vol'ba. Marketing na internete je v neustálom vývoji a v súčasnosti je intenzívne využívaný najmä $\mathrm{v}$ rámci sociálnych a multimediálnych sietí.

Ciel'om článku je poukázat' na možnosti využitia virálneho marketingu pre potreby vybraného študijného programu a zistit', či virálna reklama ako nástroj marketingovej komunikácie má vplyv na zvýšenie návštevnosti webových stránok.

Virálny marketing sa často radí medzi tzv. word-of-mouth formy marketingu. $\mathrm{V}$ preklade to znamená predávanie reklamnej informácie „od úst k ústam“. Americká asociácia Word-of-mouth marketingu (WOMMA) ju definuje ako: „Dávanie l’ud'om dôvod rozprávat' sa o produktoch a ul'ahčovat' túto konverzáciu“. Dnes sú to hlavne sociálne médiá, ktoré naplňujú túto definíciu [2].

Virálny marketing je možné charakterizovat' ako vytváranie informácie o produkte za účelom jej šírenia ústne alebo elektronicky. Elektronická cesta poskytuje tejto informácii možnost' rýchlejšieho šírenia a preto je táto forma charakteristická pre marketing na internete. Ako forma môže slúžit' text, obrázok, prezentáciu a tiež aj video. Informácia je šírená emailom a prostredníctvom d’alších prostriedkov ako sú sociálne siete, blogy alebo diskusie.

\footnotetext{
${ }^{1}$ doc. Ing. Radovan Madleňák, PhD. Katedra spojov, FPEDAS, ŽU, v Žiline. Univerzitná 1, 01026 Žilina tel.: +421415133124, e-mail: radovan.madlenak@fpedas.uniza.sk

${ }^{2}$ doc. Ing. Lucia Madleňáková, PhD. Katedra spojov, FPEDAS, ŽU, v Žiline. Univerzitná 1, 01026 Žilina tel.: +421415133125, e-mail: lucia.madlenakova@fpedas.uniza.sk

${ }^{3}$ Ing. Alena Pacherová, študentka študijného programu Elektronický obchod a manažment, Katedra spojov, FPEDAS, ŽU, v Žiline. Univerzitná 1, 01026 Žilina
} 
Ak je určitý produkt alebo služba dobrá, tak to niekto povie priatel'om a známym. Tí to zase povedia d'alej a tak sa informácia o danom produkte alebo službe vel'mi rýchlo šíri. Pokial' však šírenie neprebieha dostatočne rýchlo, celý efekt sa vel'mi rýchlo neutralizuje [3].

Virálny marketing ako moderná metóda marketingu sa použiva na šírenie komerčných oznamov najmä cez sociálne siete. Je to plánovaná činnost', ktorá motivuje k šíreniu podstaty daného oznamu. Ak je virálny marketing aplikovaný správne, môže vyvolat' oslovenie vel'kého počtu potenciálnych zákazníkov vynaložením relatívne nízkych nákladov [4]. Nevýhodou virálneho marketingu je, že výsledok môže byt' neistý a teda v konečnom dôsledku aj negatívny. Zdroj vyšle skupine l'udí správu a tí ju podl'a ich záujmu pošlú d'alej alebo si ju nechajú len pre seba. Medzi hlavné faktory možno zaradit' šíritel'ov, ktorých obsah zaujme tak, že budú ochotní šírit' ho d'alej. Nakol'ko je šírenie nekoordinované, je možné, že jeden človek dostane danú správu viackrát z rôznych zdrojov [2]. Taktiež je možné, že sa informácia počas svojho obehu bude menit' a nakoniec už nebude spíňat' svoj počiatočný ciel'.

\section{Analýza súčasného stavu virálneho marketingu v univerzitnom prostredí}

Pri analýze virálnych kampaní $\mathrm{v}$ univerzitnom prostredí sme sa zamerali v rámci zahraničia na Českú republiku, kde študenti vytvorili vel'mi zaujímavé virálne videá, ktoré prezentujú ich štúdium a školu samotnú.

Prilákat' uchádzačov k štúdiu na univerzite je t’ažká úloha. Dôležitú rolu tu hrá nie len značka školy, ale taktiež aj lokalita, študentský život, pohodlie a istá budúcnost', kde si študentov už počas výučby regrutujú firmy [1].

Je pozitívne, že vysoké školy sa menia a sú schopné vyprodukovat' komunikáciu s aspektom ,zábava“. Preto niektoré vysoké školy pozmenili svoj vizuálny štýl a chcú mladých l'udí bavit'.

\section{Univerzita Palackého v Olomouci}

Virálne video zverejnené približne pred dvomi rokmi má na sieti YouTube cez 100 tisíc vzhliadnutí. Video nám ukazuje zábery z prostredia školy a z mesta Olomouc a jeho dížka je 4 minúty. $Z$ celkového videa je možné si urobit' predstavu, že tam chceme íst', ale chýba tomu na záver pár slov, ktoré by nás mali upútat' a ešte viac prilákat' študovat' práve na tejto škole.

\section{Lesnická a dřevařská fakulta Mendelovy univerzity}

Na základe obsahu virálneho videa si pod skratkou fakulty LDF môžeme predstavit’ aj preklad ako „lahce dráždivá fakulta“. Video je profesionálne spracované a alternatívnym spôsobom prezentuje štúdium na tejto fakulte. Má dížku 2 minúty 49 sekúnd a na YouTube má cez 100 tisíc vzhliadnutí za posledný rok.

$\mathrm{Na}$ Slovensku je situácia v oblasti virálneho videa menej rozvinutá než v Čechách. Situácia je na jednej strane spôsobená nedostatočnými prostriedkami, ktoré by sa mohli vložit' do reklamy, ale na druhej strane aj slabou iniciatívou či kreativitou študentov, ale aj pedagógov. Niektoré slovenské univerzity, ktoré chcú prezentovat' seba a prilákat' študentov, majú na svojich stránkach zverejnené väčšinou len všeobecné prezentačné videá, ktoré sú skôr zamerané na všeobecné fakty [1]. Potenciálni študenti chcú ale viac, chcú niečo, čo ich zabaví.

\section{Slovenská pol'nohospodárska univerzita v Nitre}

Slovenská pol'nohospodárska univerzita so sídlom v Nitre disponuje viacerými prezentačnými videami na sieti YouTube. V spolupráci s firmou Telefónica bolo natočené

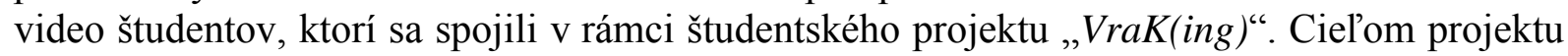
bolo revitalizovat' a obnovit' park a tým prilákat' študentov do vonkajších priestorov univerzity, kam sa budú radi vracat'. Tento projekt spĺńa tiež viacero funkcií, je prínosom ako 
pre mesto tak i pre univerzitu. Je aj jedným z faktorov, ktorý môže priláka budúcich študentov študovat' práve na Slovenskej pol'nohospodárskej univerzite v Nitre.

\section{Technická univerzita vo Zvolene}

Študenti Technickej univerzity vo Zvolene boli podobne ako študenti z Nitry iniciatívni. Študenti z fakulty ekológie a environmentalistiky vytvorili projekt „Vymeň $B A R z a$ BARiny“, ktorého zámerom bolo zmenit' prostredie okolia internátu Bariny. Ciel’om bolo vytvorit' priestor, v ktorom budú môct' študenti robit' aktivity v rámci svojho vol'ného času. Príkladom sú kultúrne akcie, pikniky alebo aj výučbu na čerstvom vzduchu. Všetky tieto fakty sú tiež dobrým motivátorom pre tých nerozhodných, ktorí nevedia, kde študovat'.

\section{Ciel' a metodika}

Ciel’om výskumu, prezentovaného v tomto článku, je aplikácia virálneho marketingu v univerzitnom prostredí. Pre overenie tvrdení boli nástroje virálneho marketingu uplatnené v podmienkach Žilinskej univerzity, študijnom programe Elektronický obchod a manažment.

Bol stanovený základný výskumný predpoklad: „Aplikovanie nástrojov virálneho marketingu pozitívne ovplyvní zvýšenie návštevnosti webovej stránky KS“.

Ako metóda výskumu bol zvolený experiment. Pre experiment boli požité tri rôzne videá virálneho charakteru. Po ich uverejnení na sieti Youtube bola analyzovaná ich popularita a návštevnost' (vzhliadnutie). Následne bola návštevnost' a počet vzhliadnutí videí porovnávaný s návštevnost'ou web stránok a FB profilu Katedry spojov [5].

\section{Výsledky a diskusia}

V nasledujúcich bodoch budú definované jednotlivé nástroje virálneho marketingu (virálne videá), ktoré boli využité pre zvýšenie návštevnosti ciel'ovej webovej stránky Katedry spojov.

\section{A. Žilinská univerzita - Katedra spojov}

Prvým nástrojom realizovanej virálnej reklamy bolo vlastné video, ktoré malo formu flash animácie [6]. Táto flash animácia prehráva humornou formou stručný príbeh študenta od začiatku štúdia až po jeho úspešné ukončenie. Posledná scéna, videa znenie: „Chceš aj ty študovat' na Katedre spojov a stat' sa inžinierom voblasti Elektronického obchodu a manažmentu alebo Poštových technológií a služieb? Navštív našu stránku Katedry spojov a dozvieš sa viac, klikaj na ks.uniza.sk“. Výsledné video bolo umiestnené na webovom portáli youtube.com [6].

\section{B. Študenti na EOaM}

Druhým videom bol výtvor študentov (v záverečnom ročníku inžinierskeho štúdia) o ich živote na Katedre spojov, Žilinskej univerzity v Žiline. Ide o domácky vytvorené video, natočené klasickou kamerou a následne zostrihané. Študenti ho vytvorili za účelom spomienky na ich pät’ rokov života na Žilinskej univerzite. Hovorili o tom kto sú, prečo sú na Žilinskej univerzite a čo im škola dala. Rozprávajú tiež o najkrajších chvíl'ach strávených na škole, ale aj o tých smutnejších momentoch, ktoré ich posunuli vpred. Na konci videa je pod'akovanie tým, ktorí im dali nové poznatky a vedomosti, s ktorými budú pracovat' v d'alších rokoch. Pozitívom tohto videa je jeho autentickost' a spontánnost', čo jedným zo znakov virálnych videí.

\section{Propagačné video Žilinskej univerzity}

Tretím a zároveň posledným videom bolo profesionálne video propagujúce Žilinskú univerzitu v Žiline. Video popisuje celkovú štruktúru univerzity a to najmä v číslach a faktoch, so súhrnom možností štúdia a uvedením možností mimo vzdelávacích aktivít. Video je ukončené heslom: „Lepšie vzdelanie, lepšia budúcnost““ s odkazom na webovú stránku Žilinskej univerzity www.uniza.sk. 


\section{Interpretácia výsledkov výskumu}

Výsledky zozbierané a spracované pomocou nástroja YouTube Analytics boli overované na základe sledovania návštevnosti webovej stránky KS. Zozbierané boli tiež údaje z návštevnosti katedrového profilu na sociálnej sieti Facebook prostredníctvom metriky Facebook Insight. Práve pomocou týchto dvoch metrík došlo k zist'ovaniu, či nástroje virálneho marketingu ovplyvnili alebo neovplyvnili návštevnost' webovej stránky KS.

Návštevnost' webovej stránky bola meraná na základe metriky Google Analytics, ktorá bola aplikovaná priamo na stránku s názvom ks.uniza.sk. Na obrázku 1 je vidiet' dennú štatistiku návštevnosti web stránky KS a tiež, kedy boli jednotlivé videá odovzdané na kanál YouTube. Signifikantný nárast zvýšenia návštevnosti stránky KS je viditel'ný včasu zverejnenia jednotlivých virálnych videí na webe youtube.com. Z metriky Google Analytics bolo zistené, že priemerné trvanie návštevy web stránok za dané obdobie bolo približne 2 minúty. Dôležitou informáciou je fakt, že za sledované obdobie prišlo na stránku KS 34,82 \% nových návštevníkov. Je možné konštatovat', že čast' nových návštevníkov mohla byt' v alokovaná práve aplikáciou nástrojov virálneho marketingu.

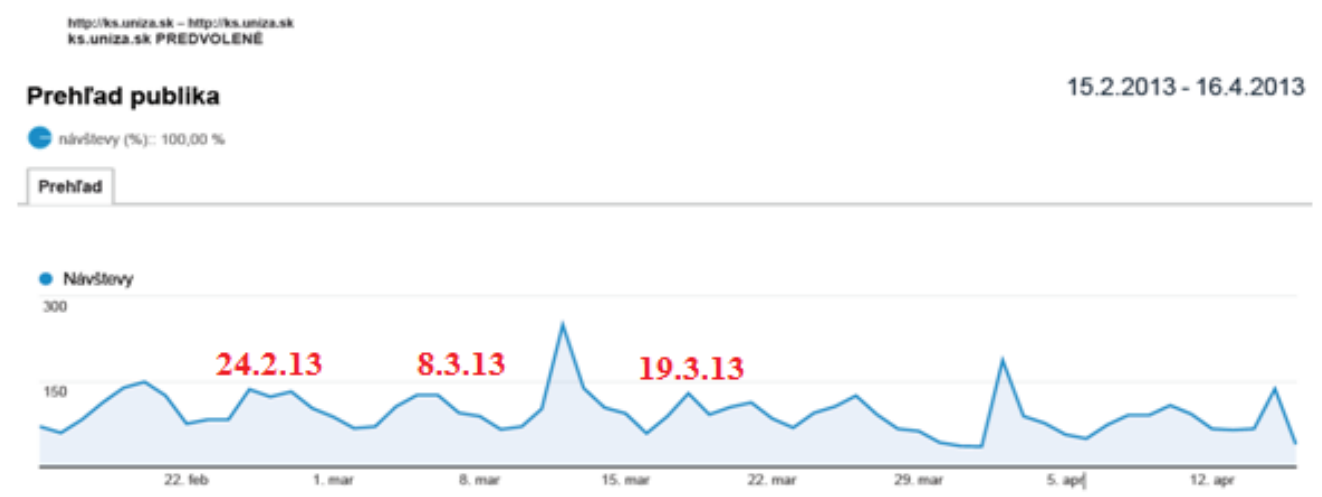

Obrázok 1. Návštevnost’ webovej stránky ks.uniza.sk (Zdroj: Google Analytics) [5]

Dôkazom je fakt, že 45,37 \% návštevníkov prichádza na stránku KS sprostredkovane. Ďalší návštevníci prichádzajú na stránku KS priamo alebo z vyhl'adávačov. Analýzou návštevnosti zo sprostredkovania je možné zistit', ktoré stránky sprostredkúvajú návštevnost' stránky ks.uniza.sk. Celková návštevnost' zo sprostredkovania bola 2617 návštev za dané obdobie od 15.2.2013 do 16.4.2013. Najväčšiu návštevnost' KS ovplyvnila fakultná stránka FPEDAS, ktorá sprostredkovala až 2038 návštev. Pre nás najdôležitejšiu návštevnost' tvorí sociálna siet' Facebook a kanál YouTube. Sprostredkovaná návštevnost' zo sociálnej siete Facebook tvorila druhú najväčšiu čast' po web stránke FPEDAS a z kanála YouTube tretiu najväčšiu skupinu návštevníkov.

Efektivita nástrojov virálneho marketingu bola hodnotená na základe metrík Google Analytics, Facebook Insights a YouTube Analytics prostredníctvom korelačnej analýzy. Porovnávaná bol návštevnost' kanálu YouTube, na ktorý boli nástroje virálneho marketingu umiestnené, s návštevnost'ou sociálnej siete Facebook a katedrovej webovej stránky ks.uniza.sk.

Obrázok 2 zobrazuje návštevnost' kanála YouTube, katedrového profilu s názvom „Katedra spojov“ na sociálnej sieti Facebook a oficiálnej stránky KS ks.uniza.sk. Na obrázku je viditel'ná vysoká návštevnost' katedrového profilu Katedra spojov, čo hovorí o sile sociálnej sieti Facebook. 


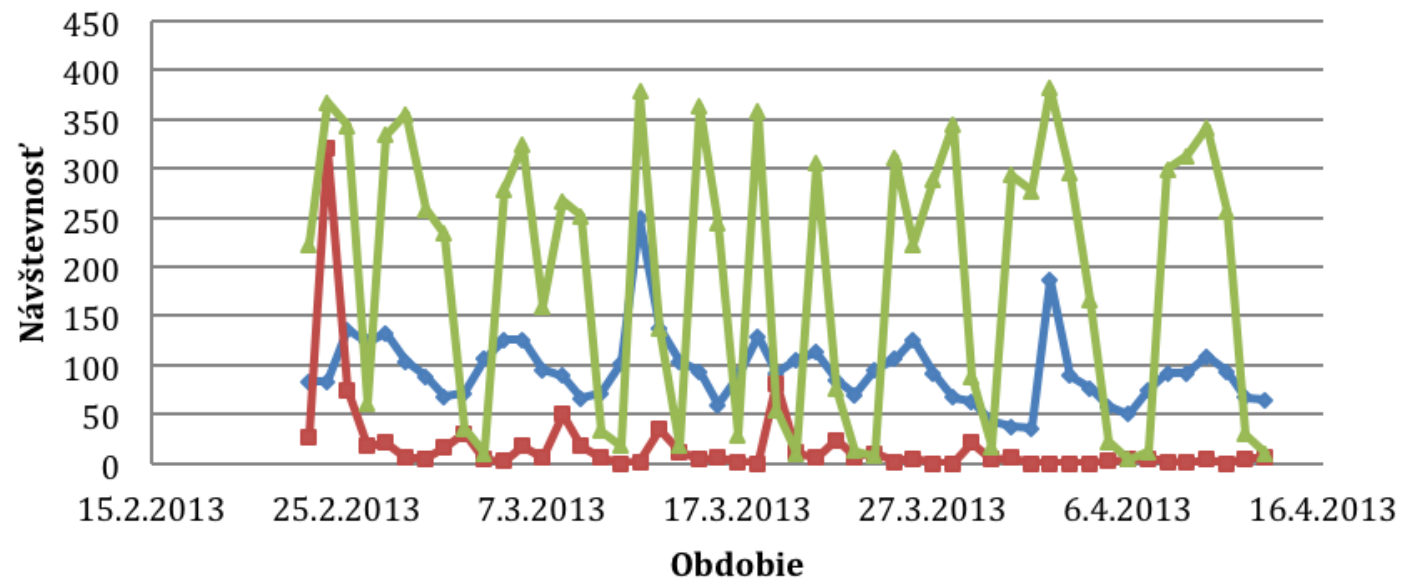

—Návštevy ks.uniza.sk $\quad \longrightarrow$ Návštevy YouTube $\quad \longrightarrow$ Návštevy Facebook

Obrázok 2. Návštevnost’ stránky ks.uniza.sk, kanála YouTube a stránky Facebook v období od 23.2.2013 do 13.4.2013 [5]

Pri porovnaní návštevnosti kanála YouTube, kde boli videá vložené, so sociálnou siet'ou Facebook, je možné povedat', že tieto dve médiá sú na sebe závislé. Väčšina videí je vkladaná primárne na YouTube, ale odtial' je následne zdiel'aná sociálnou siet'ou Facebook, kde sa medzi užívatel'mi vel'mi rýchlo šíri.

\section{Záver}

Výsledky výskumu je možné zosumarizovat' na základe troch základných ukazovatel'ov [5]:

- návštevnosti kanála YouTube, na ktorom boli umiestnené nástroje virálneho marketingu,

- návštevnosti Facebook profilu s názvom Katedra spojov na sociálnej sieti Facebook,

- návštevnosti katedrovej stránky ks.uniza.sk.

Zozbierané údaje z návštevnosti jednotlivých stránok boli spracované prostredníctvom metrík YouTube Analytics, Facebook Insights a Google Analytics. Na základe spracovania daných údajov sme merali efektivitu nástrojov virálneho marketingu. Pre výpočet efektivity nástrojov bola využitá korelačná analýza. Tabul'ka 1 sumarizuje jednotlivé nástroje viráneho marketingu (videá), obdobie ich zverejnenia a hodnotu korelačného koeficientu vypočítanú na základe ich návštevnosti.

Tabul'ka 1. Zhodnotenie efektivity nástrojov virálneho marketingu pomocou korelačného koeficientu

\begin{tabular}{|c|c|c|c|}
\hline & Obdobie & $\begin{array}{c}\text { NÁVŠTEVNOSŤ } \\
\text { YouTube vs. ks.uniza.sk }\end{array}$ & $\begin{array}{l}\text { NÁVŠTEVNOSŤ } \\
\text { YouTube vs. Facebook }\end{array}$ \\
\hline Spolu 3 videá & 23.2.13-13.4.13 & $-0,01$ & 0,14647 \\
\hline $\begin{array}{c}\text { Žilinská univerzita - Katedra } \\
\text { spojov }\end{array}$ & 23.2.13-7.3.13 & $-0,19412$ & 0,364004 \\
\hline Študenti na EOaM & 8.3.13 - 18.3.13 & $-0,12368$ & 0,045117 \\
\hline $\begin{array}{c}\begin{array}{c}\text { Propagačné video Žilinskej } \\
\text { univerzity }\end{array}\end{array}$ & 19.3.13-13.4.13 & 0,012402 & $-0,33439$ \\
\hline
\end{tabular}

Zdroj: Autori 
$\mathrm{Na}$ základe realizovaného experimentu a následne vypočítaných korelačných koeficientov medzi jednotlivými stránkami je možné konštatovat', že výskumný predpoklad „Aplikovanie nástrojov virálneho marketingu pozitívne ovplyvní zvýšenie návštevnosti webovej stránky KS“ je pravdivý.

Hodnota korelačného koeficientu ukázala, že závislost' medzi návštevnost'ou kanála YouTube a katedrovej stránky ks.uniza.sk je nízka, rovnako ako závislost' medzi návštevnost'ou kanála YouTube a katedrového profilu na sociálnej sieti Facebook.

Najvyššia závislost' sa odzrkadlila medzi návštevnost'ou kanálu YouTube a profilu na Facebooku a to dôsledkom spustenia prvého videa s názvom Žilinská univerzita - Katedra spojov. Jej hodnota bola 0.364, čo predstavuje miernu závislost'. Naopak, najnižšia závislost' bola medzi kanálom YouTube a katedrovou stránkou ks.uniza.sk a to pri spustení tretieho videa s názvom Propagačné video Žilinskej univerzity. Jeho hodnota bola 0.0124 čo predstavuje vel'mi nízku závislost'.

\section{Literatúra}

[1] ČOREJOVÁ, T., ROSTÁŠOVÁ, M.: Trends in the engineering education for ict sector in the Slovak republic. In: IETC 2011: 11th International Educational Technology Conference : may 25-27, 2011 Istanbul, Turkey, IETC, 2011. - s. 1235-1239.

[2] JANOUCH, V. Internetový marketing. Brno: Computer Press, a. s., 2010. ISBN 978-80251-2795-7.

[3] KOLAROVSZKI, P.: Emarketing and internet marketing - is it mean the same? In: MARVI - 1. ročník medzinárodnej vedeckej konferencie, Žilina 6.-7. november 2008, Žilina: Žilinská univerzita, 2008. - ISBN 978-80-8070-921-1. - s. 94-98.

[4] MAJERČÁKOVÁ, M.: Elektronické komunikácie ako podporný nástroj riadenia podniku. In: 2. Sympózium Manažment '09 : zborník príspevkov z vedeckého symposia, 16. Apríl 2009, Žilina, Slovenská republika. - Žilina: Žilinská univerzita, 2009. - ISBN 978-80-554-0063-1. - s. 171-176.

[5] PACHEROVÁ, A.: Virálny marketing v univerzitnom prostredí, diplomová práca, Katedra spojov, ŽU v Žiline, FPEDAS, 2013

[6] VACULÍK, J., MADLEŇÁK, R. Multimédiá - základné pojmy z grafického spracovania a animácie. Žilina: EDIS, 2010. ISBN 978-80-554-0194-2.

\section{Grantová podpora}

KEGA-053ŽU-4/2013 - Skvalitnenie a prepojenie kl'účových predmetov študijného programu Elektronický obchod a manažment 